\title{
Peri-Urbanization in DIY and Its Relationship to Sustainable Agricultural Lands Protection Program
}

\author{
Tita Thalia Nurcahyani ${ }^{l}$, and Djaka Marwasta ${ }^{1 *}$ \\ ${ }^{1}$ Faculty of Geography, Universitas Gadjah Mada, 55281, Sleman, Yogyakarta, Indonesia
}

\begin{abstract}
One of the main issues for cities in the world today is peri-urbanization. The rate of urbanization that occurred as an impact of industrialization resulted in a rapid population increase of urban areas. The increase of urban population causes the need of space for housing and other urban facilities also increase simultaneously, while administratively, urban area is relatively constant. The consequences is, the annexation of productive agricultural lands (especially rice fields) in the suburbs by urban functions. This study attempts to examine periurbanization and its relationship with sustainable agricultural land protection programs. This study aims to (1) assess the level of peri-urbanization in DIY; and (2) Elaborate the relationship between peri-urbanization and sustainable agricultural land protection programs. The spatial approach is used in this study considering that space is an integral part of a city which is a container for various urban activities and functions. This research is also in line with the ideas of a "sustainable city" that has been proclaimed by the United Nations (UN) and all countries in the world. The results of the study show that the implementation of regional regulations on sustainable agricultural land is quite effective in holding back the pace of peri-urbanization.
\end{abstract}

\section{Introduction}

One of the main issues for cities in the world today is the expansion of cities towards the outskirts [1], [2]. Urban physical development that goes beyond city administrative boundaries has an impact on the conversion of productive agricultural land into built-up land, decreased agricultural production, energy waste, increased pollution, and social problems in suburban areas [3]. Conversion of productive agricultural land in the suburbs is one of the impacts of urbanization. As a result, there has been a decrease in agricultural production because the area of agricultural land has decreased and the quality of human resources in the agricultural sector has tended to decline [4], [5]. This phenomenon is even more prevalent in developing countries that still rely on the agricultural sector in the national economy.

The high population growth in cities of developing countries has resulted in higher competition for land tenure in cities. The consequence of this phenomenon is the occurrence of peri-urbanization, on the grounds that land is still readily available and cheap to obtain [6]. This peri-urbanization is supported by the improvement of transportation facilities and infrastructure that connect the center and the suburbs of the city. The consequences of peri-urbanization include an increase in the level of energy use due to the increasing use of private modes of transportation.
The increase in the number of motorized vehicles has the impact of increasing levels of pollution, especially air pollution [7], [4], [8], [9], [10]. The high level of air pollution is increasingly felt in the city center and the inner membrane of the city, due to the increasing tendency of traffic jams.

Some of the empirical facts that have been researched are; according to the Natural Resource Defense Council report in 2002, in the United States between 1960 and 1990, more than twice as much land has emerged as a result of the encroachment of the metropolitan city, while the population has only increased by less than half [11], [3]. It is noted that the average addition of newly built land is 148 hectares per hour. Kushner in 2006 presents the fact that in Atlanta between 1975 and 1992 there was a reduction of 1,540 square kilometers of vegetated land to built up land as a result of urban expansion. Atlanta is the least populated city among other cities in America (only a quarter of the population density of Los Angeles).

This periurbanization phenomenon also occurs in Indonesia, especially in Java. One of the areas experiencing periurbanization symptoms is DIY. The following is a graph of population numbers and population growth rates in Sleman, one of the districts in DIY that experienced the highest periurbanization.

\footnotetext{
* Corresponding author: jakamar@ugm.ac.id
} 


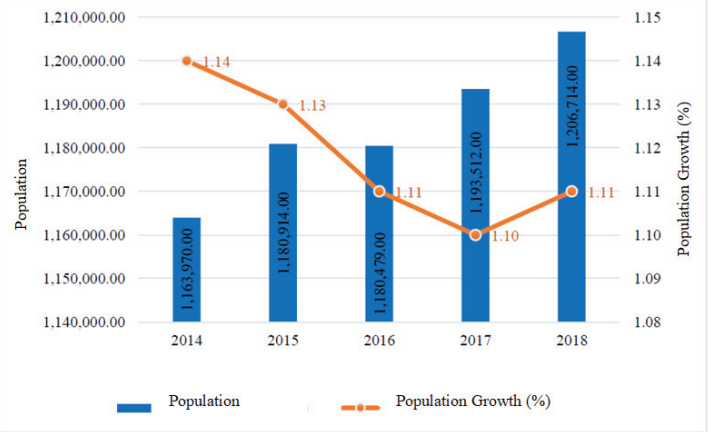

Fig. 1. Population and Its Growth Graphs of Sleman.

This research attempts to examine peri-urbanization and its relationship with sustainable agricultural land protection programs. The spatial approach will be used in this study considering that space is an integral part of a city which becomes a container for various urban activities and functions. This research is also related to the ideals of a "sustainable city" that has been proclaimed by the United Nations (UN) and all countries in the world [12]. The study conducted in this research emphasizes the spatial aspects, especially the analysis of spatial processes, and their impact on physical and social space.

\section{Research Problem}

Urban Sprawling is a dilemma problem faced by many metropolitan cities in developing countries. Meet the two primary human needs (food and housing) at the same time as well as same space, become a big dilemma. Fulfilling food needs requires productive agricultural lands, while providing the needs for housing forces city residents to seize fertile agricultural lands.

This phenomenon is very worrying for the future of farmers and the agricultural sector. Agricultural production is degraded because productive agricultural lands are converted into built-up land. Limitation of productive agricultural lands conversion into built up areas is required firmly, but it must be based on appropriate and accountable reasons.

DIY is an example of an area experiencing this massive land conversion occurence. To minimize the conversion of agricultural land to non-agricultural land, the Yogyakarta Regional Government have established regional spatial plans listed in the DIY Regional Regulation No.5 of 2019. Simultaneously, Sleman Regency as a part of DIY also launch the Regional Regulation of Sleman Regency No.12 of 2012. Spatial planning is very important, because Sleman Regency has high agricultural potential and is the main source of food production to support regional and national food supply. DIY government has also established a sustainable food agriculture area as part of the policy to protect sustainable food agriculture land, and is listed in the DIY Regional Regulation No. 10 of 2011 concerning the Protection of Sustainable Food Agricultural Land.

From the description above, there are two problems faced in the research area: (1) What is the peri- urbanization rate in DIY ?; and (2) How does the PERDA-regulated sustainable agricultural land protection program affect peri-urbanization process? Based on that research problems, this study aims to: (1) assess the level of peri-urbanization in DIY; and (2) Elaborate the relationship between peri-urbanization and sustainable agricultural land protection programs.

\section{Research Methods}

Based on the research objectives, this research is an exploratory-descriptive study, it aims to determine the process of periurbanization and its effects on environmental conditions. The analytical approach used is a deductive approach. In the deductive approach, it starts with a general study of phenomena first, then is used as a basis for understanding more specific phenomena.

In relation to the research object, this research used survey method, which is to observe and measure various variables used to assess the process and effect of periurbanization. The data collection technique uses a sampling methods, which is in the form of an area sample. The analysis used is mainly spatial analysis. The household sampling technique used was purposive sampling. The reason for determining the selected sample is its level of importance.

Based on the analytical method, this research is a quantitative research. The location of this research is DIY. Specifically, the research location is focused more in the Sleman Regency. This location was chosen based on the consideration of the phenomenon of periurbanization and the existence of a local regulation on sustainable agricultural land protection. The condition of the research area is in the form of fertile agricultural lands around the city of Yogyakarta which have a high level of productivity, but have become the locus for the expansion of the urban area of Yogyakarta. As a result, many agricultural lands have been invaded and converted into developed land. This phenomenon is quite in accordance with the objectives of the research which is to examine the process and impact of periurbanization.

To be able to study the peri-urbanization process carefully, administrative boundaries and morphological boundaries are used together. The boundaries used to determine the morphological boundaries of urban refer to Pryor (1968), which is areas that have more than $75 \%$ urban land use. In addition, this study also uses the types of urban physical growth as suggested by [13], [14], [15] as a reference for determining the urban development process in the study area.

This research is including in the field of geography with the main focus on the spatial approach. The main object of study study is the phenomenon of urban encroachment towards the outskirts (peri-urbanization) with an emphasis on assessing urban function invasion, tracing the variables and factors involved in the process of encroachment, and their effects on agricultural land.

The identification of spatial process is carried out by tracing the increasing of urban built land in the last 10 years (2011-2020). Multi-time satellite imagery is used 
as a data source as the basis for spatial analysis by overlapping maps between two time basis. This identification process is intended to obtain a picture of the peri-urbanization that has occurred. The activities carried out in this research include: interpretation of digital images in the laboratory, observation and physical measurements in the field, and data analysis. Activities in the laboratory include: maps making, maps overlying, compiling a field observation checklist and tracing secondary data, compiling a questionair for informants, and determining area samples.

Field activities carried out included interviews of several informants, especially from the bureaucracy and farmers. Secondary data documentation and field photographs were also carried out during field activities. Research activities were resumed in the laboratory for the process of field data input, data editing, statistical analysis, and presentation of some research information. To support all research activities in accordance with these procedures, several sets of materials and tools, variable measurements, procedures for determining the population, samples and units of analysis are needed, as well as data analysis procedures.

The data used in this study are primary and secondary data. Primary data is data obtained from direct observations and/or measurements in the field or identified from research materials directly in the laboratory. Some of the primary data collected in this study are maps of satellite imagery interpretation, field observation data, and data taken from interviews with selected respondents. Secondary data is data obtained from another sources, either from existing publications and reliable data validity and accuracy, or data obtained from previous research results. Some of the secondary data collected in this study include thematic maps, tables and or graphs (especially population data), and publications from various agencies as well.

The stages carried out in this research include (1) the pre-field stage; (2) stage of field activities; and (3) the post-field stage. The pre-field stage is a series of activities related to preparation to support the implementation of field activities, covering a variety of activities ranging from literature studies, tracing secondary data, preparation of research materials to be used in the field (list of fields and field maps), and sample determination. area and informants.

Some indicators and how to measure a sustainable agricultural land protection program is obtained by comparing the area of agricultural land stipulated in the PERDA as sustainable agricultural land with changes in actual land use. This comparison is taken by using of the Geographical Information System. The sustainable indicator is determined by the percentage of the area of sustainable agricultural land that still remains as existing agricultural land.

The data analysis framework in this study consists of two types, namely spatial analysis and correlation analysis. The spatial analysis is intended to answer the first objective of the study, which is the identification of peri-urbanization process. Correlation analysis is used to elaborate on the second research objective, which is to examine the relationship between peri-urbanization and the implementation of sustainable agricultural land protection programs. Figure 2 shows the flow of research activities stages.

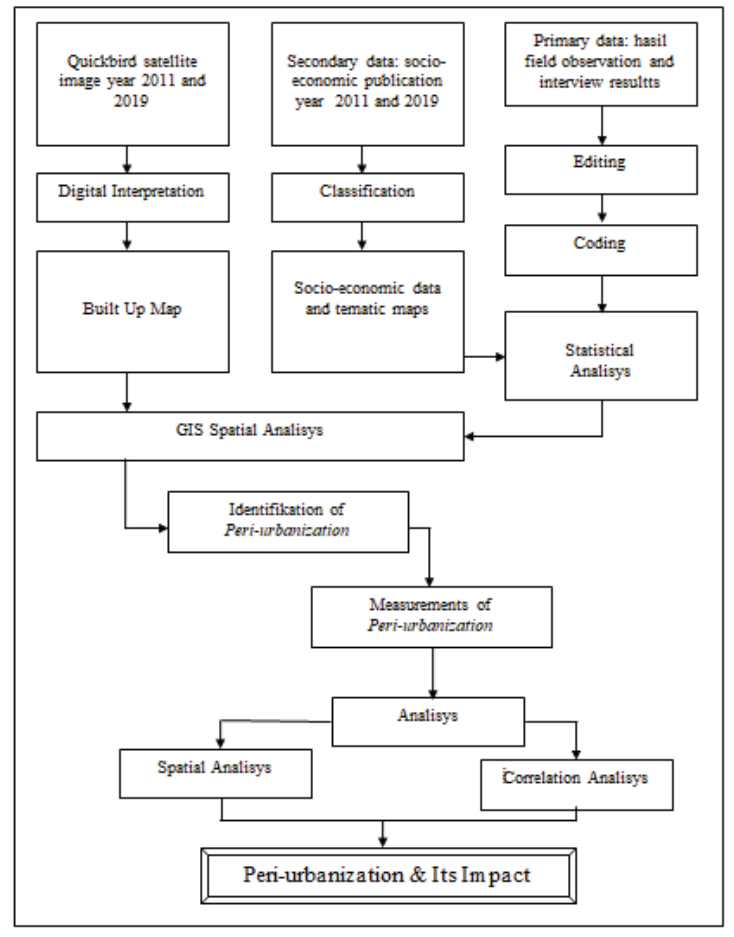

Fig. 2. Research Methods Flow Chart

To determine the agricultural land shortening process, it is carried out by using a spatial approach. The data that has been obtained are processed using ArcGIS software and processed using the overlaying method of zoning maps for sustainable food agriculture and land use maps in Sleman Regency to determine the area of agricultural land. Then the data obtained is calculated using the Conversion Rate formula (V) as follows:

$$
V=\frac{L_{t}-L_{t-1}}{L_{t-1}} \times 100
$$

$\mathrm{V}=$ agricultural land shortening (\%)

$\mathrm{Lt}=$ agricultural area in year $\mathrm{t}$

Lt-1 = agricultural area before year $\mathrm{t}$

A negative $\mathrm{V}$ value indicates that existing agricultural land are experiencing land conversion or depreciation.

\section{Literature Reviews}

The world's population continues to increase from year to year. According to the United Nations, the world's population has doubled in a period of 50 years between 1950, from 3 billion to 6 billion in 2000 [16]. The high total population growth of the countries in the world is mostly contributed by the population growth in developing countries.

In the context of developing countries, the high population growth in urban areas is more dominant due to the uncontrolled rate of urbanization. Cities as centers 
of socio-economic and cultural activities have experienced growth in line with population growth, both non-physical (social, economic, political and cultural) and physical growth. However, many cities that are experiencing growth actually have a negative impact on the physical and sociocultural environment in and around them [17]. Expectations regarding a city that can provide a safe, comfortable, and prosperous place for its residents have not been realized because the growth of the city, especially the growth in population and building density, is not as expected.

In a global context, a new form of urban development is characterized by the appearance of a new concentration of labor and urban activities in areas outside the city center, as a result of the flexibility of production systems and technology [18], [19]. In the era of 1980 to 1990 , from several dictionaries appeared several terms related to urbanization such as edge city, megalopolis, technoburbs, flexspace, peperoni-pizza cities, a city of realms, superburbia, disurb, perimeter cities, outer cities, technopolis, heteropolis, exopolis and perimetropolitan bow waves. In France, the term periurbanisation is used to refer to any place outside the city and its surroundings with a function as a place to live. The term rurbanisation was introduced around 1970 which is used to be the same as periurbanisation.

Urban area is a term used to identify an area that has a large population, is based on a non-agricultural economy, and its land use is dominated by developed land [20], [21], [22]. The definition of a city or urban area can be viewed from various perspectives, including juridical-administrative, morphological (physical), demographic (population), population density, functional in organic areas, and socio-economic [23]. Although urban areas can be viewed from various perspectives, in general the boundaries of urban areas are always related to: (1) population (number and or population density); (2) spatial function (economic basis); and (3) morphology.

An urban area is an area that has an atmosphere of modern life and life which is characterized by, among others: (1) Facilities and infrastructure for urban life (buildings, housing, transportation, communication, industry, recreation, etc.); and (2) specific social, economic, cultural, political, demographic [24] [25] [26]. To be categorized as an urban area, an area must meet certain requirements, which is called the urban threshold. Each country has its own urban threshold standard. For example, it can be stated that the urban threshold standard according to the SMSA (Standard of Metropolitan Statistic Area) in effect in the United States includes: (1) a minimum population of 50,000 people; (2) non-agricultural land use is more than $75 \%$, (3) workers in the city center are more than $15 \%$ or workers who live in the city center are more than $25 \%$, (4) there are public transportation facilities; and (5) more than $50 \%$ of high density settlements (according to a certain threshold), in this case the United States uses a minimum population density of 1000 people per square mile [30] in [27].

In Indonesia, Law Number 18 of 1965 has been stipulated which regulates the boundaries of an area as a city or an urban area, namely an area with a population of more than 50,000 people [28]. Based on the hierarchy, there are three city hierarchies according to this Law, namely Kota Praja with a population of between 50,000 and 75,000, Municipal City with a population of between 75,000 and 100,000 , and Kota Raya with a population of more than 100,000 . In line with the high population growth, especially in urban areas, this limit changes. Based on Law Number 5 of 1974, for regions in Java, a minimum limit of 150,000 people is defined as cities, while outside Java, the minimum limit is 50,000 people [23].

There are several terms related to the definition of urban, including city, urban areas, and urbanity. City is a term to indicate a certain area associated with the authority of regulating territory by the city government [1]. An urban area is an area bounded by juridical administrative boundaries and is under the authority of the city government. Urbanity is areas that have the characteristics of a city, both in physical, social, economic and cultural terms. In Law No. 22/1999, it is explained that what is meant by urban areas is an area that has non-agricultural main activities, with the arrangement of the functions of the area as a place for urban settlements, centralization and distribution of government services, social services, and economic activities.

Conceptually, urban areas are easy to define, but in practice the delineation of urban boundaries is not easy to do. To limit urban areas, especially from a morphological (physical) point of view, a clear definition of urban land is required. Urban land can generally be divided into functional and physical definitions. Urban functionally related to industrial activities, settlements, trade, services, and so on. Physically associated with high population density and land cover (land use), which is characterized by built-up lands.

Some experts have described quantitatively to limit urban land use, one of which is Pryor. The concept put forward is based on the percentage of urban land use, the percentage of rural land use and the percentage of distance from the main urban land to the main rural land which are members of the rural-urban land use triangle. Urban areas are characterized by residential land, commercial land, and industrial land with a higher density than the average density for rural areas. Rural areas are characterized by a lower population density, a higher proportion of vacant land and agricultural land, as well as changes in land use and non-dynamic daily population mobility to urban areas [2].

Pryor made a model based on a gradual transformation from city to village or vice versa village to city, where the farther away from the real urban area, the more blurred the urban appearance and the clearer the distant decay principle. Morphologically, the closer to the urban area, the dominance of urban land use forms is getting bigger. There are 4 gradual zones from urban to rural areas, namely:

(1) Urban areas

(2) Suburban areas

(3) Rural areas

(4) Rural areas 
Based on the Pryor model, suburban areas are areas located between urban built-up land and areas with a maximum urban land use area of $50 \%$, and vice versa are rural areas.

One of the interesting phenomena of peri urban urban areas in Asia is the existence of commuters. Commuters in developing countries are low-income people who are trying to find additional income in cities. Over time, it turns out that in this peri-urban area pockets of very good quality and luxurious settlements appear, so that the activities of moving from the suburbs are also carried out by the upper class, although there are not many of them.

\section{Results and Discussion}

Two important findings in this study are (1) periurbanization process that occurred in DIY; and (2) the relationship between the implementation of regional regulations for the protection of perpetual agricultural land and the periurbanization process. The discussion about the findings of this study focuses on that two issues.

\subsection{Periurbanization Process}

This research was conducted in Sleman Regency, DIY. Sleman Regency is an area that has the largest fertile agricultural land and at the same time has experienced intensive land conversion. Figure 3 shows an administrative boundary of Sleman Regency.

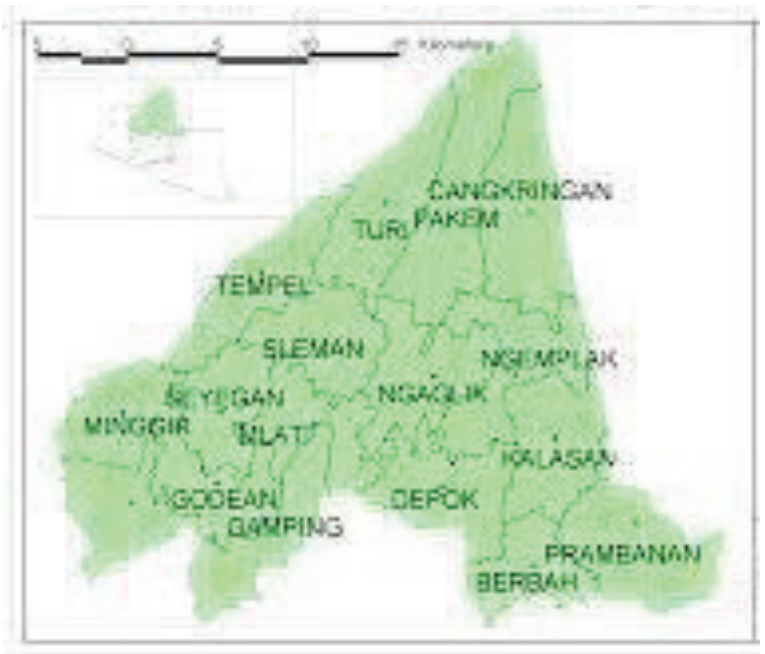

Fig. 3 Administrative Map of Sleman Regency

The conversion of fertile agricultural land to built up land mainly occurs in areas adjacent to the city of Yogyakarta. This process is known as periurbanization. The positive impact of the periurbanization process is an increase in economic growth, and this has happened in Sleman Regency. Figure 4 is a graph of the economic growth rate for 5 years.

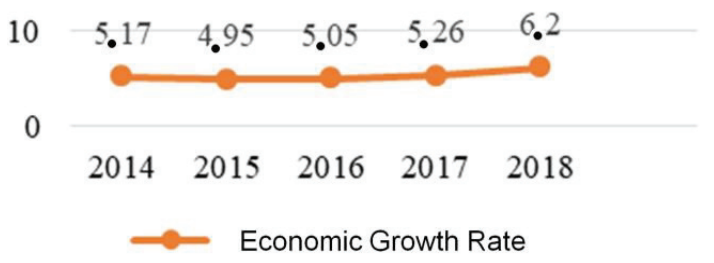

Fig. 4 Economic Growth Rate of Sleman Regency

Based on the graph, it can be seen that the rate of economic growth in Sleman Regency is always increasing, and this is due to the conversion of agricultural land to developed land.

Referring to BPS data for 2020, the area of agricultural land always tends to decline, on the other hand, developed land always tends to increase. Table 1 shows the changes in land area for each land use.

Table 1. Landuse Change in Sleman Regency (Ha)

\begin{tabular}{|c|l|c|c|c|c|c|}
\hline No & Landuse & 2014 & 2015 & 2016 & 2017 & 2018 \\
\hline 1 & Housing & 18,591 & 18,627 & 18,756 & 18,786 & 18,823 \\
\hline 2 & Ricefield & 24,719 & 24,628 & 24,577 & 24,550 & 24,517 \\
\hline 3 & Dry Field & 3,924 & 3,922 & 3,922 & 3,922 & 3,918 \\
\hline 4 & Forest & 53 & 53 & 53 & 53 & 53 \\
\hline 5 & Bare land & 1,264 & 1,264 & 1,264 & 1,264 & 1,264 \\
\hline 6 & Others & 8,932 & 8,989 & 8,911 & 8,908 & 8,908 \\
\hline & Total & \multicolumn{5}{|c|}{57,483} \\
\hline
\end{tabular}

Source: BPS Sleman, 2020 [29]

Most of the conversion of agricultural land to developed land occurs on fertile land. Thus, it can be stated that periurbanization has a positive impact on the urban economy, but has a negative impact on agricultural production. To anticipate the worsening impact of periurbanization on agricultural production, the government has enacted a regional regulation on perpetual agricultural land. The hope is that food security will not be threatened by the uncontrolled periurbanization process.

The regional regulation has stipulated that protected lands do not change their function. The procedure is that the government will not issue title certificates if the agricultural land which is designated as perpetual rice field is converted into developed land. Figure 5 shows the distribution of paddy fields designated as perennial agricultural land in Sleman Regency. 


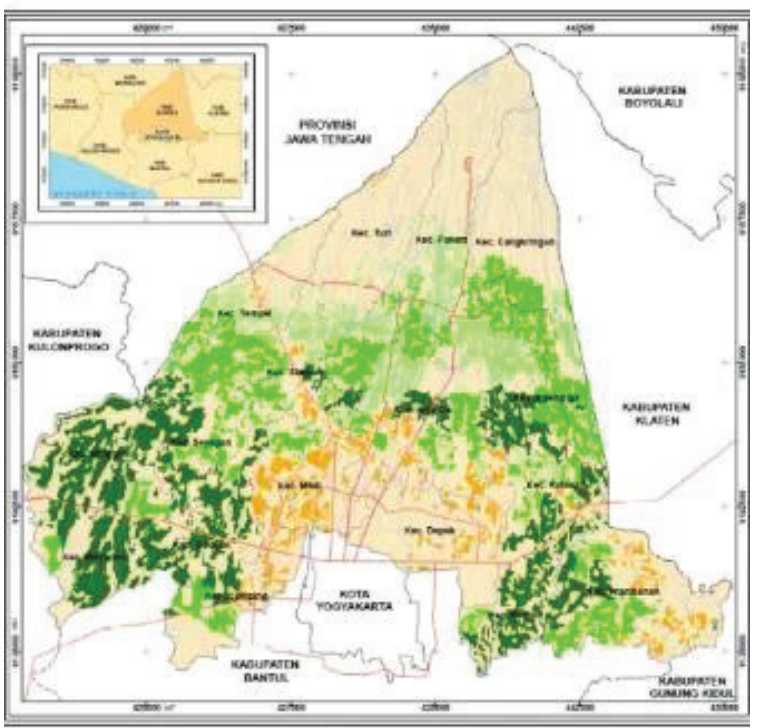

Fig. 5 Sustainable Agricultural Land Distribution

\subsection{Relationship between periurbanization and agriculture land protection}

Since the Yogyakarta Special Region and Sleman regencies enacted regional regulations on perpetual agricultural land, the rate of periurbanization has decreased. In Figure 5, it can be seen that since 2013, the rate of conversion of agricultural land has decreased. This is the impact of the implementation of the Perpetual Paddy Field Regional Regulation.

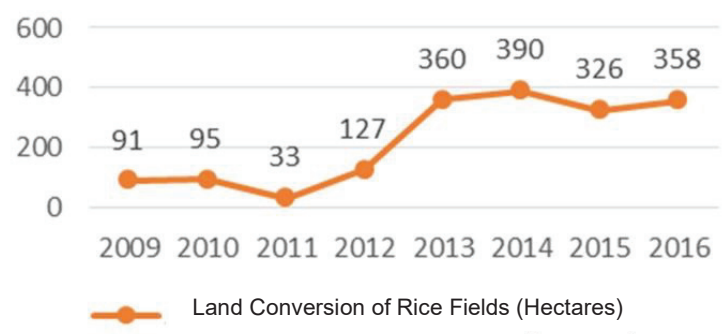

Fig. 6. Trends of Land Conversion in Sleman

Along with the times and population growth, land conversion is mostly done to meet human needs. Change in land use or land use change or commonly referred to as land conversion is a change in the function of part or all of the land area from its original function to another function one time to the next

Land conversion is the process of changing the use of part or all of the land from its original function to other functions. The agricultural land that decreased causes a decreasing of agricultural production. The conversion of paddy fields is the most intensive land use change for conversion to settlement as a result of population growth. Agricultural land conversion generally occurs in two stages, namely the land owner relinquishing his rights to non-farmers, then followed by the new owner using the agricultural land for non-agricultural activities.
Land conversion tends to be in line with population growth. The rate of population growth will indirectly affect the conversion of agricultural land to developed land and settlements. The high rate of population growth will be directly proportional to the growth rate of settlements. The factors that directly affect land conversion are the growth of infrastructure development including transportation facilities, land growth for industry, and growth of residential facilities, while indirectly influenced by population, economic structure, urbanization, and consistency in the implementation of the spatial plan.

The increase in population results in increased population pressure on land and an impact on land use changes. Changes in land use in general can occur because of the need to meet the needs of an increasing population and increasing demands for a decent quality of life. There are three important factors that cause agricultural land conversion, namely: 1) external factors which are the main factors caused by the dynamics of urban development, demography and economy; 2) internal factors, namely factors arising from farmers and agricultural land owners due to the crisis in their socioeconomic conditions; 3) the policy factor, namely the regulatory aspect that regulates everything concerning agricultural land that has been determined by the central and regional governments.

Land conversion from agriculture to non-agriculture can have a negative impact on agriculture, either directly or indirectly. The direct impact is a decrease in agricultural production capacity and an increase in food problems, while the indirect impacts include damage to the irrigation system in agricultural production areas due to built-up land, loss of investment that has been invested in building reservoirs, irrigation networks, and printing rice fields. In addition, land conversion also has a negative impact on social activities, such as loss of livelihoods as farmers, reduced job opportunities and income opportunities for farming and all economic activities that intersect with farming. The impact of land conversion will be permanent because most of the converted land has never been returned to agricultural land.

Sustainable agriculture is the management of resources to meet basic human needs for clothing, food and signage while maintaining the quality of the natural environment itself and preserving it. To create sustainability, an appropriate policy is needed. Policy is an effort or action that is strategic in the long term and comprehensive to achieve the desired goals. The central and local governments have made several policies for land control and protection. However, at the present time we still encounter a lot of land that is still being converted.

\section{Conclusions}

1. Periurbanization rate in DIY, especially in Sleman Regency, tent to be very high before year 2013, and declining since year 2013. 
2. Regulation of sustainable agricultural land protection program (PERDA) affected to reducing peri-urbanization process.

Very high appreciation to Faculty of Geography Universitas Gadjah Mada, which provide an opportunity to conduct this research, and to all of the informants involved in this research.

\section{References}

1. Yunus, H.S., Megapolitan: Konsep, Problematika, dan Prospek, Yogyakarta: Pustaka Pelajar (2006)

2. Yunus, H.S., Dinamika Wilayah Peri Urban: Determinan Masa Depan Kota, Yogyakarta: Pustaka Pelajar (2008)

3. Paterson, R., Handy, S., Kockelman, K., Bhat, C., Rajamani, J., Jung, J., Banta, K, Desai, U., and Waleski, J., Techniques for Mitigating Urban Sprawl, Center for Transportation Research, The University of Texas at Austin (2003)

4. Kahn, M.E., The Environmental Impact of Suburbanization. Journal of Policy Analysis and Management; 19(4):569-586. (2000)

5. Hess, G., Just What is Sprawl, Anyway? Journal of City and Regional Planning; 26 (2):pp 11-26. (2001)

6. Yunus, H.S., Perubahan Penggunaan Lahan di Daerah Pinggiran Kota: Kasus di Pinggiran Kota Yogyakarta; Disertasi, Yogyakarta: Universitas Gadjah Mada, Yogyakarta (2000)

7. Freeman, L., The Effects of Sprawl on Neighborhood Social Ties. Journal of the American Planning Association; 67(1):69-77( 2001)

8. Duncan, J.E., The Search for Efficient Urban Growth Patterns. Tallahassee, FL: Florida Department of Community Affairs (1989)

9. Burchell, R.W. and Shad, N.A., The Evolution of the Sprawl Debate in the United States, West Northwest Winter; 5(2):137-160 (1999)

10. Frank, J.E., The Costs of Alternative Development Patterns: A Review of the Literature, Washington, DC: Urban Land Institute (1989)

11. Benfield, F.K, Raimi, M.D., and Chen, D.D.T., Once There Were Greenfields:How Urban Sprawl is Undermining America's Environment, Economy and Social Fabric, Washington DC: Natural Resources Defense Council (1999)

12. Yunus, H.S., Pembangunan Kota Berkelanjutan: Permasalahan dan Strategi Pencapaiannya, Yogyakarta: Universitas Gadjah Mada, Yogyakarta (2004)

13. Ellman, T., Infill: the cure for sprawl? Arizona Issue Analysis $146 . \quad$ [online] URL:http://www.urbanfutures.org/p82897.html (1997)

14. Antrop. M., Changing Patterns In The Urbanized Countryside Of Western Europe, Landscape Ecology, Vol 15. Pp: 257-270 (2000)
15. Wilson, E.H., Development Of A Model To Quantify and Map Urban Growth, University of Connecticut (2002)

16. United Nations, World Urbanization Prospects The 2001 revision Data Tables and Highlights. ESA/P/WP.173.http://www.un.org/esa/population/p ublications/ wup2001/wup2001dh.pdf (accessed 20 Jan. 2006)

17. Parker, S., Urban Theory and the Urban Experience: Encountering the City, London: Routledge (2004)

18. Fujita, M., Krugman, P., and Venables, A.J., The Spatial Economy:Cities, Regions, and International Trade, Cambridge: MIT Press (1999)

19. Pendall, R., Fulton, W. and Harrison, A., Losing Ground to Sprawl? Density Trends in Metropolitan America. Fair Growth: Connecting Sprawl, Smart Growth, and Social Equity; Georgia World Congress Center, Atlanta Georgia. Washington, DC: Fannie Mae Foundation (2000)

20. Pacione, M., Urban Geography: a Global Perspective (2nd Edition), London: Routledge (2005)

21. Herbert, D.T., and Thomas, C.J., Urban geography: A First Approach, Chichester: Wiley (1982)

22. Witherick, M., Ross, S., and Small, J., A Modern Dictionary of Geography (4th edition), New York: Oxford University Press (2001)

23. Yunus, H.S., Manajemen Kota: Perspektif Spasial, Yogyakarta: Pustaka Pelajar (2005)

24. Knox. P.L., Urban Geography: An Introduction to Urban Geography, New Jersey: Prentice Hall (1994)

25. Bintarto, Interaksi Desa-Kota dan Permasalahannya, Jakarta: Ghalia Indonesia (1989)

26. Bintarto, Urbanisasi dan Permasalahannya, Jakarta: Ghalia Indonesia (1986)

27. US Census Bureau, [Web Page]; accesed 15 Oktober 2008; URL:http://www.census.gov (2000)

28. Yunus, H.S., Klasifikasi Kota, Yogyakarta: Pustaka Pelajar (2005)

29. BPS, Statistik Propinsi DIY 2020, BPS Propinsi DIY (2020)

30. Pryor, R.J.. Defining The Rural-Urban Fringe. Social Force. Vol. 47. Issue 2. Pp: 202-215. (1968) 